Urodynamic studies show a high prevalence of unstable bladder activity in such patients but no consistent abnormality. ${ }^{2-4}$

About $15 \%$ of children have enuresis at 5 and about $2 \%$ at $16 .^{5}$ Both sexes are equally affected among these young adults, but three distinct groups may be identified. Firstly, there are those who have only nocturnal enuresis: they are likely to be dry by age 25 . Secondly, there are those with the enuretic syndrome: they have diurnal frequency, urgency, and urge incontinence as well as enuresis. The third group with recurrent enuresis are those who have relapsed after a variable period of being dry. In these second and third groups symptoms may persist for years and perhaps for life. One study of 65 consecutive adults with enuresis showed that 13 had only nocturnal enuresis, 36 the enuretic syndrome, and 16 recurrent enuresis. ${ }^{4}$ Most of the patients were under 30 , and those who still had symptoms at 25 were likely to continue to have them.

As enuresis is a functional disorder examination of the patient, microbiological examination of the urine, and an excretion urogram will not show any abnormality. The functional bladder capacity may be reduced, ${ }^{6}$ but this will be shown only if the patient keeps a careful record: over one week he should record the volumes of urine voided and the episodes of incontinence. This simple exercise is often neglected, yet it provides useful information for the doctor and feedback for the patient. Few adults know how much their bladder holds or how much urine they produce during a night's sleep.

Many treatments are available: conditioning techniques such as bladder drill'; drugs such as tricyclic antidepressants, anticholinergics, and desmopressin ${ }^{8}$; and, finally, for selected cases operative procedures such as bladder transection' or enterocystoplasty. ${ }^{10}$ Ideally management should follow a rational sequence, but in practice this plan is often complicated by the psychosocial aspects of the condition.

We are now doing better at treating patients with urinary incontinence. The multidisciplinary Association of Continence Advisors was founded in 1981, and a report in 1983 from the King's Fund has encouraged public education on incontinence. " A report last year from the Royal College of Physicians suggested that all health districts should have a continence service, ${ }^{12}$ and continence nurse advisers have now been appointed in many districts. An adult with enuresis who has not responded to treatment needs the support of such continence services.

R C L FENELEY

Consultant Urologist,

Bristol and Weston District Health Authority,

Bristol BS1 3NP

1 Miller A. Adult enuresis. Br f Urol 1966;38:697-9.

2 Torrens MJ, Collins DC. The urodynamic assessment of adult enuresis. $\mathrm{Br} \mathcal{F}$ Urol 1975;47: 433-40.

3 Whiteside EG, Arnold EP. Persistent primary enuresis: a urodynamic assessment. $\mathrm{Br} \mathrm{Med} \mathcal{F}$ 1975;i:364-7.

4 Hindmarsh JR, Byrne PO. Adult enuresis-a symptomatic and urodynamic assessment. $\mathrm{Br} \mathcal{J}$ Urol 1980;52:88-91.

5 Miller FJW. Children who wet the bed. Bladder control and enuresis. London: Heinemann, 1973: 47-52. (Clinics in developmental medicine; Nos 48/49.)

6 Starfield B. Functional bladder capacity in enuretic and non-enuretic children. $f$ Pediatr 1967;70:777-81.

7 Jarvis GJ. Bladder drill for the treatment of enuresis in adults. Br $\mathcal{G}$ Urol 1982;54:118-9.

8 Ramsden PD, Hindmarsh JR, Price DA, Yeates WK, Bowditch JDP. DDAVP for adult enuresis-a preliminary report. $\mathrm{Br} \mathcal{F}$ Urol 1982;54:256-8.

Hindmarsh JR, Essenheigh DM, Yeates WK. Bladder transection for adult enuresis. Brf Urol 1977;49:515-21.

$10 \mathrm{Bramble}$ FJ. The treatment of adult enuresis and urge incontinence by Enterocystoplasty. $\mathrm{Br} \mathcal{J}$ Urol 1982;54:693-6.

11 King Edward's Hospital Fund for London. Action on incontinence. Project paper no 43. London: King's Fund Centre, 1983. (Chairman: JC Brocklehurst.)

12 Royal College of Physicians of London. Physical disability in 1986 and beyond. $\mathcal{F}$ R Coll Physicians Lond 1986;20:160-94.

\section{Respiration and connective tissue diseases}

"Connective tissue diseases" is an unsatisfactory term for several illnesses in which immune disturbances cause widespread inflammatory damage to organs. Except in scleroderma, this damage does not primarily affect connective tissue. Autoantibodies to intracellular antigens are a common, though not universal, feature. The main value of the term is to group several diseases of unknown and probably diverse aetiology that have similar clinical features and may be diagnostically confused. Their diversity is well illustrated by their range of effects on the respiratory system.

Weakness of the muscles of ventilation and deglutition commonly accompanies the inflammatory myopathiespolymyositis and dermatomyositis ${ }^{1}{ }^{2}$-and pneumonitis after aspiration is an important cause of death in severely affected patients. ${ }^{2}$ Inflammatory myopathy is also a feature of scleroderma and systemic lupus erythematosus. Myasthenic muscle weakness should not be overlooked. Myasthenia gravis, polymyositis, and systemic lupus erythematosus share at least one disease susceptibility gene inherited in the major histocompatibility complex ${ }^{3}$ and combinations of these diseases occur more frequently than would be expected by chance. ${ }^{4}$

Pleural disease is common in systemic lupus erythematosus $^{5}$ and is occasionally accompanied by the life threatening complication of "shrinking lungs" in which reduced lung volumes occur together with a striking elevation of the diaphragm. ${ }^{6} 7$ The aetiology of this condition is not understood, and it often does not run in parallel with overall disease activity. ${ }^{6}$ Affected patients may have weak inspiratory muscles, ${ }^{6} 7$ but the association with pleuritic chest pain and linear atelectasis on chest radiographs suggests that this is not the whole explanation. Some patients with "shrinking lungs" have reduced pulmonary compliance. ${ }^{7}$ Pneumonitis with loss of surfactant is an alternative explanation for the reduced lung volumes.

Pulmonary fibrosis is prominent in patients with scleroderma. There is some recent evidence ${ }^{8}$ that penicillamine may have some beneficial effect on the pulmonary fibrosis of scleroderma but the effect is not striking. Pulmonary fibrosis is also seen in patients with polymyositis, rheumatoid arthritis, Sjögren's syndrome, and systemic lupus erythematosus. Patients with polymyositis are more likely to have pulmonary fibrosis, Raynaud's phenomenon, and the sicca syndrome ${ }^{9}{ }^{10}$ if they also have autoantibodies to the antigen Jo-1 (histidyl tRNA synthetase), ${ }^{11}$ but the autoantibodies probably do not directly cause inflammation.

Why particular organs are affected in these multisystem diseases is poorly understood. The lungs are especially susceptible to inflammatory damage from inhaled substances which may potentiate and localise the effects of other diseases-an example is the extensive pulmonary fibrosis seen rarely in coal miners with rheumatoid arthritis. ${ }^{12}$ Cigarette smoking much more commonly incites pulmonary disease-for example, pulmonary haemorrhage in Goodpasture's syndrome is largely restricted to smokers. ${ }^{13}$ Presumably autoantibodies against basement membrane achieve access to pulmonary basement membrane only in the damaged alveoli of smokers.

Obstruction of small airways is extremely common, though usually mild, in patients with rheumatoid arthritis, ${ }^{14-16}$ scleroderma, and Sjögren's syndrome. The obstruction occurs in 
non-smokers, and smoking probably has an additive rather than synergistic effect. Lymphoid infiltration of the mucus glands of the airways and the salivary and lachrymal glands may lead to the triad of dry cough, dry eyes, and dry mouth in Sjögren's syndrome. ${ }^{17}$ More serious effects on the airways include chondritis of the tracheal rings in relapsing polychondritis and obliterative bronchiolitis in rheumatoid arthritis.

Pulmonary vascular disease may cause some of the more unpleasant complications of the connective tissue diseasespulmonary hypertension, pulmonary haemorrhage, and thromboembolic disease. Pulmonary hypertension is a feature of scleroderma and of systemic lupus erythematosis, and pulmonary vasospasm induced by cold may be associated with Raynaud's phenomenon in scleroderma ${ }^{18}$-but the evidence that this is the cause of the pulmonary hypertension is not convincing. A link has been suggested between pulmonary hypertension in systemic lupus erythematosus and antibodies to negatively charged phospholipids (anticardiolipin antibodies), ${ }^{19}$ and these antibodies are correlated with thrombosis and platelet hyperreactivity. Again no causal relation has been established between anticardiolipin antibodies and pulmonary hypertension.

Some patients with apparently isolated pulmonary disease may have connective tissue diseases. Patients with cryptogenic fibrosing alveolitis may have hyperglobulinaemia and antinuclear antibodies, a combination which has been associated with Raynaud's phenomenon and digital vasculitis. $^{20}$ Similarly primary pulmonary hypertension affects mostly women of child bearing age-that is, the same group who suffer from connective tissue disease-and Raynaud's phenomenon, hyperglobulinaemia, and other features of systemic lupus erythematosus are more common in patients with this disease than in the general population.

Acute pulmonary and pleural inflammation often respond well to steroid and cytotoxic drugs, but severe irreversible airways obstruction, pulmonary fibrosis, and pulmonary hypertension usually respond poorly, although a trial of treatment should be attempted.

Infection, drug toxicity, and malignancy should all be considered in patients with connective tissue disease. Pulmonary shadows in patients with systemic lupus erythematosus are often caused by infection, and the diagnosis of systemic lupus erythematosus pneumonitis should be made by exclusion. ${ }^{21}$ Solitary pulmonary nodules should always be fully investigated. Both disease and treatment may increase the risk of opportunistic infection, and bronchoscopy and needle biopsy are commonly indicated. Even open lung biopsy may be necessary to make a diagnosis.

MARK J WALPORT

Senior Lecturer,

Rheumatology Unit,

Department of Medicine,

Royal Postgraduate Medical School,

London W12 0HS

1 Dickey BF, Myers AR. Pulmonary disease in polymyositis/dermatomyositis. Semin Arthritis Rheum 1984;14:60-76.

Medsger TA, Robinson H, Masi AT. Factors affecting survivorship in polymyositis: a life-table study of 124 patients. Arthritis Rheum 1971;14:249-58.

3 Batchelor JR, Welsh KI. Association of HLA antigens with disease. In: Lachmann PJ, Peters DK, eds. Clinical aspects of immunology. Oxford: Blackwell, 1982:283-306.

Sovadjian JV, Enriquez P, Silverstein MN, Pepin J-M. The spectrum of diseases associated with thymona. Coincidence or syndrome? Arch Intern Med 1974;134:374-9.

5 Segal AM, Calabrese LH, Ahmad M, Tubbs RR, White CS. The pulmonary manifestations of systemic lupus erythematosus. Semin Arthritis Rhewm 1985;14:202-24.

systemic lupus erythematosus. Semin Arthritis Rhewm 1985;14:202-24.
Gibson GJ, Edmonds JP, Hughes GRV. Diaphragm function and lung involvement in systemic ibson GJ, Edmonds JP, Hughes GRV. Diaphragm
lupus erythematosus. Am $\mathcal{Y}$ Med 1977;63:926-32.

7 Jacobelli S, Moreno R, Massardo L, Rivero S, Lisboa C. Inspiratory muscle dysfunction and unexplained dyspnoea in systemic lupus erythematosus. Arthritis Rheum 1985;28:781-8.
8 Steen VD, Owens GR, Redmond C, Rodnan GP, Medsger TA. The effect of D-penicillamine on pulmonary findings in systemic sclerosis. Arthritis Rheum 1985;28:882-8.

9 Yoshida S, Akizuki M, Mimori T, Yamagata H, Inada S, Homma M. The precipitating antibody to an acidic nuclear protein antigen, the Jo-1, in connective tissue diseases. A marker for a subset of polymyositis with interstitial pulmonary flbrosis. Arthritis Rheum 1983;26:604-11.

10 Bernstein RM, Morgan SH, Chapman J, et al. Anti-Jo-1 antibody: a marker for myositis with interstitial lung disease. BrMed f 1984;289:151-2.

11 Mathews MB, Bernstein RM. Myositis autoantibody inhibits histidyl-tRNA synthetase: a model for autoimmunity. Nature 1983;304:177-9.

12 Caplan A. Certain unusual radiological appearances in the chest of coalminers suffering from rheumatoid arthritis. Thorax 1953;8:29-37.

13 Donaghy M, Rees AJ. Cigarette smoking and lung haemorrhage in nephritis caused by autoantibodies to glomerular basement membrane. Lancet 1983;ii:1390-3.

14 Hyland RM, Gordon DA, Broder I, et al. A systematic controlled study of pulmonary abnormalities in rheumatoid arthritis. F Rheumatol 1983;10:395-405.

15 Geddes DM, Webley M, Emerson PA. Airways obstruction in rheumatoid arthritis. Ann Rheum Dis 1979;38:222-5.

16 Vitali C, Viegi G, Tassoni S, et al. Lung function abnormalities in different connective tissue diseases. Clin Rheumatol 1986;5:181-8.

17 Strimlan CV, Rosenow EC, Divertie MB, Harrison EG. Pulmonary manifestations of Sjogren's syndrome. Chest 1976;70:354-61.

18 Wise RA, Wigley F, Newball HH, Stevens MB. The effect of cold exposure on diffusing capacity in patients with Raynaud's phenomenon. Chest 1982;81:695-8.

19 Asherson RA, Oakley CM. Pulmonary hypertension and systemic lupus erythematosus. f Rheumatol 1986;13:1-5.

20. Holgate ST, Haslam P, Turner-Warwick $M$. The significance of antinuclear and DNA antibodies in cryptogenic fibrosing alveolitis. Thorax 1983;38:67-70.

21 Hunninghake GW, Fauci AS. Pulmonary involvement in the collagen vascular diseases. Am Rev Respir Dis 1979;119:471-503.

\section{Christ Church conference on postgraduate education-25}

\section{years on}

The Christ Church conference of 1961 chaired by Sir George Pickering' led to one of Britain's most successful experiments in postgraduate medical education. Within 10 years postgraduate centres had been established in most district hospitals and honorary clinical tutors had been appointed from among the consultants to oversee education for all local doctors and dentists. A striking feature was the enthusiasm with which local communities-doctors and laymenresponded to requests for money and facilities.

The overwhelming impression of the recent follow up conference, held appropriately at Green College, Oxford, was that complexity, confusion, and uncertainty had replaced the clear sighted objectives of the early years. While the necessity for postgraduate education is accepted, awkward questions remain. What is the evidence that it is a good thing? Is it value for money? Are its methods sufficiently evaluated by audit and peer review? Are the people who provide it skilled in educational techniques? And perhaps most difficult of all: How are the conflicting requirements of the National Health Service (service to patients), the General Medical Council, the royal colleges and faculties, and the universities (education and training of doctors) to be reconciled?

A complex educational bureaucracy, unintelligible to outsiders, preserves the status quo by deferring to vested interests and accepting rigid requirements for training. A hospital, for example, may be visited by inspecting teams from the university to look at the preregistration year, the royal colleges and faculties to look at senior house officer and registrar posts in each specialty, and specialist advisory committees to look at senior registrar posts. Each team makes independent recommendations to its parent body. Such visits are expensive and time consuming if carried out properly. How much more sensible it would be to have a single national inspecting body, as in North America and Australia, that would accredit hospitals rather than posts and consider service provision as well as educational facilities. 